\title{
Literasi Privasi di Sosial Media: Analisis Kesadaran Privasi pada Grup Facebook Komunitas Peduli HBV (Hepatitis B Virus) di Indonesia
}

\author{
Arina Faila Saufa ${ }^{*}$; Shofwan Yusuf ${ }^{2}$ \\ ${ }^{1}$ Program Studi Ilmu Perpustakaan, Universitas Islam Negeri Sunan Kalijaga \\ ${ }^{2}$ Program Magister Ilmu Komunikasi, Universitas Gadjah Mada \\ *Korespondensi: arina.saufa@uin-suka.ac.id
}

\begin{abstract}
Hepatitis is a virus that attacks the liver and causes cirrhosis or inflammation of the liver to cause cases of death. To date some hepatitis patients experience discrimination in various forms that forced them to hide the disease they may have. On the other hand, social media provides an opportunity hide their identity and privacy related to the disease. This study aims to determine the extent of privacy awareness of Facebook Group named "Concerned $H B V$ (Hepatitis B virus)" in Indonesia. Data was collected and analysed by using content analysis. The analysis was consists of observing Facebook post on the HBV Care Facebook group starting from May 2019 to April 2020 to find out the privacy awareness of the media users. The results showed that of 281 picture posts there were 151 images that did not have relevance to privacy awareness, 91 images that showed privacy awareness, and 39 images that showed privacy unconsciousness. If only observing images that have relevance to privacy awareness, then there are 130 images with $70 \%$ showing privacy awareness and 30 showing privacy unconsciousness. Researchers suggested that there are still 30\% of Facebook users did not show their life privacy, which then it requires further studies related to privacy literacy in a broader and deeper context.
\end{abstract}

Keywords: content analysis; social media; facebook; data privacy

\begin{abstract}
Abstrak
Hepatitis merupakan virus yang menyerang hati dan menyebabkan sirosis atau peradangan hati hingga menyebabkan kasus meninggal dunia. Didasari oleh kekhawatiran akan penularan, beberapa penderita hepatitis mendapatkan diskriminasi dalam berbagai bentuk. Hal itu membuat sebagian penderita hepatitis memilih menyembunyikan kasus penyakitnya agar tidak diketahui orang lain. Berbeda dengan dunia fisik, sosial media menyediakan kesempatan anonimitas bagi penggunanya sehingga membuka peluang untuk lebih mudah menyembunyikan identitas beserta privasinya terkait penyakit. Namun bagaimanakah jika pengguna sosial media tersebut adalah penderita hepatitis yang cenderung menyembunyikan identitasnya karena kekhwatiran akan diskriminasi, mungkinkah mereka sepenuhnya memiliki literasi akan privasi di media sosial. Penelitian ini bertujuan untuk mengetahui sejauh mana kesadaran privasi pengguna grup Facebook "Komunitas Peduli HBV (Hepatitis B virus)" di Indonesia. Penelitian ini dilakukan dengan menganalisis konten media sosial yang menjadi obyek dari study ini. Analisis dilakukan terhadap postingan berupa foto pada grup facebook Peduli HBV mulai bulan Mei 2019 hingga bulan April 2020 untuk mengetahui kesadaran privasi pengguna media tersebut. Hasil analisis data menunjukkan bahwa dari 281 postingan gambar terdapat 151 gambar yang tidak memiliki relevansi dengan kesadaran privasi, 91 gambar yang menunjukkan kesadaran privasi, serta 39 gambar yang menunjukkan ketidaksadaran privasi. Jika hanya mengamati gambar yang memiliki relevansi dengan kesadaran privasi, maka terdapat 130 gambar dengan 70\% menunjukkan kesadaran privasi dan 30 menunjukkan ketidaksadaran privasi. Peneliti menyimpulkan bahwa masih terdapat 30\% pengguna Facebook menunjukkan ketidaksadaran privasi. Hal ini membuka kesempatan untuk dilakukan penelitian lanjutan terkait literasi privasi dalam konteks yang lebih luas dan mendalam.
\end{abstract}

Kata Kunci: media sosial; analisis konten, facebook, literasi data;

\section{PENDAHULUAN}

Hepatitis merupakan sebuah virus yang menyerang hati. Virus ini menyerang inangnya pada tahap tertentu yang akan mengakibatkan sirosis atau peradangan hati hingga berujung kematian. Ada kurang lebih 240 juta orang, atau hampir setara penduduk Indonesia saat ini, terinfeksi virus hepatitis B (HBV) kronis dan 75 persen di antaranya tinggal di Asia. Sekitar 600.000 pasien yang terinfeksi meninggal setiap tahun karena penyakit yang berhubungan dengan Virus Hepatitis B tersebut (Yano, Utsumi, Lusida, \& Hayashi, 2015). Mengutip data yang diterbitkan oleh Kementerian Kesehatan tahun 2012, total penderita hepatitis B di Indonesia tahun 2007 mencapai 
angka 13 juta jiwa (Citizen.org, 2012). Dari jumlah yang besar tersebut, menjadikan Indonesia sebagai negara endemisitas tertinggi kedua di setelah Myanmar (Nadila \& Rahman, 2019).

Sebagai negara dengan kasus hepatitis yang tergolong tinggi, penderita hepatitis tidak terlepas dari adanya diskriminasi. Marzuita, dari Komunitas Peduli Hepatitis, menyebutkan bahwa dalam satu tahun, kurang lebih ada 10 keluhan diskriminasi di tempat kerja (Republika, 2017). Hal tersebut juga diperkuat dengan pernyataan Dokter Irsan Hasan, ketua Perhimpunan Peneliti Hati Indonesia, yang menyebutkan bahwa 50 persen pengidap hepatitis mengalami diskriminasi (Detik, 2018). Adapun bentuk diskriminasinya beragam termasuk ditolak bekerja ketika ketahuan memiliki penyakit hepatitis saat skrining kesehatan calon karyawan karena mempertimbangkan hepatitis sebagai penyakit menular, atau begitu ketahuan ada orang sakit hepatitis langsung dipisahkan tempat makannya seperti diberikan piring kertas khusus maupun gelas kertas sekali pakai untuk mereka. Berbagai deskriminasi terhadapt penderita hepatitis sebenarnya juga sudah terjadi di China maupun Vietnam (Han et al., 2018; Le et al., 2019).

Ada berbagai sumber informasi untuk mendapatkan pengetahuan terkait hepatitis. Mulai dari jurnal penelitian, buku kesehatan, media cetak seperti surat kabar dan majalah, media elektronik seperti radio dan televisi, media online berbasis internet hingga situs-situs jejaring sosial. Sebagian masyarakat awam cenderung tidak merujuk pada jurnal penelitian untuk mendapatkan pengetahuan terkait hepatitis. Adapun asumsi peneliti adalah masyarakat awam cenderung mendapatkan informasi mengenai hepatitis dan berbagai permasalahannya lewat media baik konvensional maupun media baru. Data Asosiasi Jasa Pengelola Internet Indonesia (2018) menyebutkan bahwa 64,8 persen atau sekitar 171,17 juta masyarakat Indonesia telah menggunakan internet. 18.9 persen di antaranya menggunakan internet untuk mengakses sosial media dan Facebook menjadi konten internet (media sosial) yang paling sering dikunjungi dengan persentase 50.7 persen. Artinya lebih dari seperempat penduduk di Indonesia mengakses Facebook sebagai media sosial dengan tingkat keseringan paling tinggi.

Di Indonesia ada beberapa grup atau komunitas di Facebook terkait virus hepatitis yaitu "Komunitas Peduli HBV (Hepatitis B Virus)" dengan jumlah anggota terbesar yakni lebih dari 1.500 dibanding dengan grup "Penderita Hepatitis B (HBsAg+)" dengan jumlah anggota 722. Dari 1500 lebih anggota dalam grup tersebut tidak dapat dilacak dengan pasti manakah di antara anggota tersebut yang merupakan akun anonim dan manakah akun real yang mencerminkan kesesuaian akun Facebook dengan pemiliknya di dunia fisik. Pertimbangan atas hal itu menjadi penting setidaknya bagi penderita hepatitis mengingat peluang permasalahan diskriminasi yang akan terjadi kepada mereka. Artinya permasalahan privasi dalam bentuk informasi privat lebih mudah untuk dijaga di dunia jejaring sosial karena penderita hepatitis dapat menyembunyikan identitasnya. Hal ini menjadi berbeda dari dunia fisik di mana seorang menjadi tidak leluasa menyembunyikan identitasnya untuk berinteraksi dengan orang lain dalam konteks privasi dan implikasinya.

Permasalahan mengenai privasi tidak berhenti pada tataran dunia fisik saja. Semakin berkembangnya zaman, pembahasan privasi juga turut berkembang konteksnya. Potter (2019) menyebutkan bahwa masalah privasi telah tumbuh secara signifikan selama 2 dekade terakhir karena teknologi informasi yang lebih baru telah mengubah cara informasi dihasilkan, disimpan, dan dibagikan. Potter (2019) menyebut bahwa privasi ditandai oleh seperangkat gagasan. Adapun gagasan tersebut di antaranya adalah: (1) Seseorang tidak ingin membagikan semua informasi tentang diri mereka kepada semua orang. Artinya ada sebagian hal terkait diri mereka yang tetap ingin untuk dipertahankan dan tidak disebarluaskan; (2) privasi adalah kondisi variabel. Maksudnya yaitu seseorang mungkin ingin berbagi sedikit informasi dengan beberapa orang tertentu saja, sekaligus menutup akses kepada pihak tertentu. Misalnya, nomer telepon yang tetap diberikan kepada teman dan kolega tapi tidak ingin disebarkan kepada pihak pengiklan, atau riwayat penyakit yang dipercayakan kepada dokter namun tidak untuk teman, saudara, bahkan 
orang tua; (3) Seseorang memiliki informasi pribadi mereka dan harus dapat mengendalikannya. Artinya ketika seseorang atau sebuah organisasi menggunakan informasi pribadi tanpa ijin, maka hal tersebut mengarah kepada sebuah pelanggaran privasi; (4) Ketika kita berbagi beberapa informasi pribadi dengan orang lain dan menetapkan batasan untuk membagikan informasi itu, kita mengharapkan orang itu untuk menghormati batasan kita.

Hal yang cukup mengkhawatirkan di tengah kemajuan teknologi dan kemudahan yang adalah seseorang tersebut menjadi terlena dan tidak kritis. Dijk (2012) menyesalkan bahwa banyak orang secara tidak sadar telah menyerahkan privasi mereka yang berisiko menjadi boomerang. Hasil penelitian memang menunjukkan bahwa perilaku online pengguna memang seringkali ceroboh (Barth, et. al, 2019). Aktivitas-aktivitas meninggalkan jejak seperti: menggesek kartu debit/kredit, transaksi uang digital, pembayaran elektronik, hingga posting di media sosial misalnya dapat berakhir pada berbagai efek yang tidak terbayangkan sebelumnya. Kombinasi data warehousing dan data mining, bahkan pada tahap surveylance, dapat menyebabkan hal-hal seperti gagal mendapatkan pinjaman atau gagal mendapatkan pekerjaan. Hal ini menjadi sangat relevan dengan para penderita hepatitis manakala mereka secara tidak sengaja mengekspos penyakitnya di media sosial yang dapat berujung pada ditolaknya pekerjaan saat proses profiling oleh perusahaan.

Prananda (2020) menyebutkan bahwa data rekam medis merupakan hak pribadi individu yang bersifat rahasia dan terbatas dalam studi kasus Covid-19. Hasil penelitian yang dilakukan oleh DePuccio et. al (2020) dalam konteks Covid-19 juga menyebutkan bahwa pasien yang ada di rumah sakit khawatir tentang siapa yang memiliki akses ke informasi medis mereka. Dari kasus covid-19 tersebut, begitu pula seharusnya dengan kasus hepatitis yang juga penting untuk memastikan bahwa catatan medis merupakan sesuatu yang sensitif bagi isu privasi. Hal tersebut dikarenakan catatan medis dapat menjadi jendela ke masa lalu seseorang. Dari sebuah catatan medis, juga dapat menjadi sebuah jendela informasi ke masa depan. Meskipun ramalan ke masa depan menjadi hal yang belum tentu akurat dan sempurna, namun beberapa ramalan dapat dilakukan misalnya: riwayat diabetes yang tidak disiplin dalam pengobatan dapat cenderung berakhir dengan kebutaan, orang dengan riwayat depresi dapat berujung pada percobaan bunuh diri, termasuk orang dengan riwayat hepatitis dapat berujung pada kanker hati dan kondisi lemas. Ramalan-ramalan tersebut mejadi penting bagi perusahaan untuk pertimbangan dalam melakukan rekrutmen karyawan. Hal ini menjadi relevan apabila seseorang meninggalkan jejak digital di media sosial dengan beberapa indikasi yang mengarah kepada sebuah kasus yang sensitif seperti hepatitis misalnya.

Dari kemajuan teknologi dan kemudahan yang ditawarkannya, berikut dengan konsekuensi yang ditimbulkannya, maka pemahaman terkait keputusan dan konsekuensi akan privasi merupakan hal yang penting bagi seseorang. Pemahaman tentang keputusan dan konsekuensi yang timbul akibat permasalahan privasi sebagai sebuah kontrol informasi oleh pengguna dapat disebut sebagai literasi privasi. Park (2013) menyatakan bahwa relasi literasi digital dan privasi memiliki prinsip untuk mendukung, mendorong, dan memberdayakan pengguna untuk melakukan kontrol atas identitas digital mereka. Givens (2014) mendefinisikan literasi privasi sebagai sebuah tingkat pemahaman dan kesadaran seseorang tentang bagaimana informasi dilacak dan digunakan dalam lingkungan online dan bagaimana informasi itu dapat mempertahankan atau kehilangan privasinya. Definisi literasi privasi berfokus pada pemahaman tentang tanggung jawab dan risiko yang terkait dengan berbagi informasi secara online, literasi digital berfokus pada penggunaan informasi berdasarkan tugas dalam lingkungan digital (Wissinger, 2017). Artinya, secara singkat bahwa pemahaman akan literasi privasi menjadi penting karena tidak semua orang yang berinteraksi dengan media online mampu mengelola privasi mereka bahkan mungkin belum memahami perihal pentingnya privasi itu sendiri.

Permasalahan mengenai kesadaran privasi tidak terlepas dari kemampuan literasi digital. Dana Rotman (2009) memberikan acuan tentang literasi privasi dengan menawarkan 5 elemen 
kerangka kerja literasi digital sebagai berikut: 1) Memahami, yaitu konteks privasi yang berbeda dalam spektrum informasi pribadi, dan tempatnya dalam interaksi online: informasi pengenal diri berbeda dari pengaktifan akses informasi, dan ini, pada gilirannya, berbeda dari informasi ekspresif. Masing-masing memiliki peran yang berbeda dalam interaksi sosial, dan interaksi mereka harus diketahui dan dipahami, 2) Mengenali yaitu berbagai tempat online di mana informasi pribadi dibagikan. Sebagian besar pengguna terbiasa dengan keadaan di mana identifikasi informasi diungkapkan. Mereka kurang akrab dengan hasil interaksi sosial online, dan siap mengungkapkan diri mereka secara visual dan emosional di media sosial yang berbeda. Memahami bahwa hampir setiap interaksi sosial online memerlukan tingkat paparan tertentu akan menyebabkan kesadaran yang lebih besar tentang implikasi paparan tersebut, 3) Menyadari merupakan implikasi berbagi informasi pribadi dalam situasi sosial. Bahkan pengguna yang paham komputer dapat dikacaukan oleh kemungkinan tak terbatas untuk pelanggaran privasi yang mungkin terjadi selama interaksi sosial online. Foto-foto pengguna yang berpesta selama kuliah dapat menjangkau calon perusahaan; pesan pribadi di komunitas online atau blog dapat dibaca oleh audiens yang tidak beralasan. Realisasi seberapa jauh jangkauan dan seberapa lama informasi sosial itu, harus mengarahkan pengguna ketika berinteraksi online, 4) Mengevaluasi adalah kemungkinan ancaman terhadap privasi dalam interaksi yang diberikan. Hal ini dimungkinkan ketika pengguna memiliki pengetahuan yang cukup dan mampu menilai manfaat, dan 5) Memutuskan adalah elemen terakhir dari literasi privasi adalah memutuskan secara sadar informasi mana yang akan dibagikan, dalam keadaan apa. Ini adalah langkah proaktif, yang diambil oleh pengguna yang berpendidikan, berdasarkan pengetahuan dan pemahamannya tentang berbagai masalah privasi.

Menyebut privasi di dunia digital, penelitian yang dilakukan oleh Puspitasri (2017) memperlihatkan bahwa kesadaran terhadap privasi tidak mempengaruhi kepercayaan remaja terhadap Facebook. Artinya Facebook, sebagai salah satu situs jejaring sosial, tetap digunakan oleh penggunanya terlepas dari kesadaran terhadap privasi. Selain itu, survey yang dilakukan oleh Batmetan et. al (2018) menyatakan bahwa pengguna layanan publik merasa tidak peduli dengan permasalahan privasi. Sejalan dengan penelitian yang dilakukan oleh Saidah \& Irwansyah (2019) terkait relasi paradoks antara permasalahan privasi dan kebebasan dalam berekspresi di dunia maya. Hal ini menjadi semakin menarik apabila pengguna media tersebut sekaligus juga seorang pengidap virus hepatitis (atau memiliki kerabat sebagai pengidap virus hepatitis) yang cenderung menyembunyikan kasusnya agar tidak diketahui orang lain. Apakah mereka juga tidak peduli dengan privasi atau menunjukkan sikap lainnya. Berdasarkan latar belakang tersebut, penelitian ini mencoba untuk menjawab sejauh mana kesadaran privasi oleh pengguna grup Facebook "Komunitas Peduli HBV (Hepatitis B Virus)" di Indonesia. Penelitian ini menjadi penting mengingat penelitian terdahulu belum memperlihatkan urgensi subjek penelitian dalam menjaga privasi, sedangkan penelitian ini menyadari hal tersebut. Hal ini sekaligus menjadi kontribusi penelitian ini, di mana aspek urgensi kesadaran privasi berdampak langsung terhadap subjek penelitian sehingga memperkaya kajian literasi privasi.

\section{METODE PENELITIAN}

Penelitian ini dilakukan dengan menggunakan metode kuantitatif, di mana fakta-fakta yang didapat kemudian diolah menjadi data (Sugiyono, 2015). Penelitian dilakukan dengan berfokus pada fakta-fakta komunikasi yang berlangsung pada grup Facebook "Komunitas Peduli HBV (Hepatitis B virus)" yang mengarah pada masalah privasi. Teknik pengumpulan data dilakukan melalui observasi non partisipan dan dokumentasi, di mana peneliti ikut bergabung ke dalam grup tersebut dan hanya melakukan pengamatan tanpa terlibat dalam diskusi maupun percakapan sedangkan dokumentasi dilakukan dengan cara melakukan unduh gambar dan atau screenshot gambar (Sugiyono, 2015). Teknik sampling yang digunakan adalah purposif, sampel 
data yang digunakan adalah semua gambar atau foto yang terdapat dalam grup Facebook "Komunitas Peduli HBV (Hepatitis B virus)" yang dikirim sejak Mei 2019 hingga April 2020. Pengumpulan data dilakukan pada minggu pertama bulan Juni tahun 2020. Pemilihan sampel kurun waktu satu tahun terakhir diharapkan mampu memberikan gambaran kondisi terkini terkait objek penelitian.

Dalam penelitian ini metode analisis data menggunakan analisis konten kuantitatif. Proses analisis data dilakukan setelah proses pengumpulan data yang telah dilakukan kategorisasi, Kategori pertama yaitu gambar yang tidak memiliki relevansi terkait kesadaran privasi, kategori kedua yaitu gambar yang menunjukkan kesadaran privasi, dan kategori ketiga yaitu gambar yang menunjukkan ketidaksadaran privasi. Kemudian dianalisis dengan merujuk pada kerangka kerja literasi digital oleh Dana Rotman (2009). Analisis konten dilakukan dengan menganalisis bentuk konten komunikasi untuk mendapatkan pesan yang sifatnya menyeluruh. Secara ringkas Eriyanto (2011) menjelaskan analisis konten kuantitatif sebagai teknik penelitian ilmiah yang ditujukan untuk mengetahui gambaran karakteristik isi. Analisis konten digunakan demi mengidentifikasi isi komunikasi yang tampak secara sistematis (manifest), dan dilakukan secara objektif, valid, reliabel, dan dapat direplikasi. Dalam hal ini, analisis konten komunikasi dilakukan pada gambar atau foto yang telah dikumpulkan dari grup Facebook "Komunitas Peduli HBV (Hepatitis B virus)" untuk mengetahui pesan-pesan yang disampaikan melalui gambar-gambar tersebut. Uji reliabilitas dilakukan oleh dua orang pengkoder sekaligus peneliti, yakni Shofwan Yusuf dan Arina Faila Saufa. Persamaan yang digunakan untuk menghitung data yang diperoleh dari kedua pengkoder menggunakan persamaan Holsti . Dalam persamaan ini CR menyatakan Koefisien Reliabilitas, M menyatakan Jumlah yang disetujui dua pengkode, dan N1 + N2 adalah Jumlah pernyataan yang diberi pengkode (Kriyantono, 2014), berikut persamaannya,

$$
C R=\frac{2 M}{N I+N 2}
$$

\section{HASIL DAN PEMBAHASAN}

Dari pengumpulan data yang dilakukan, didapati bahwa terdapat 281 gambar pada grup Facebook "Komunitas Peduli HBV (Hepatitis B virus)" yang diposting sejak Mei 2019 hingga April 2020. Dari sejumlah 281 gambar tersebut, tersebar cukup merata bahkan menunjukkan grafik yang semakin meningkat. Pada bulan Mei tahun 2019 terdapat 9 postingan gambar, dan pada bulan Desember tahun 2019 terdapat 47 postingan gambar. Grafik tahun 2019 menunjukkan pola yang semakin meningkat dari bulan Mei 2019 hingga bulan Desember 2019. Pada tahun 2020 bulan Januari terdapat 14 postingan gambar kemudian pada bulan April tahun 2020 terdapat 26 postingan gambar. Peningkatan aktivitas yang dilakukan para anggota grup tersebut menunjukkan bahwa grup facebook "Komunitas Peduli HBV (Hepatitis B virus)" merupakan grup yang aktif. Hal ini dapat dilihat pada gambar 1 yang menggambarkan adanya peningkatan aktivitas terhitung dari bulan Mei 2019 hingga April 2020. 


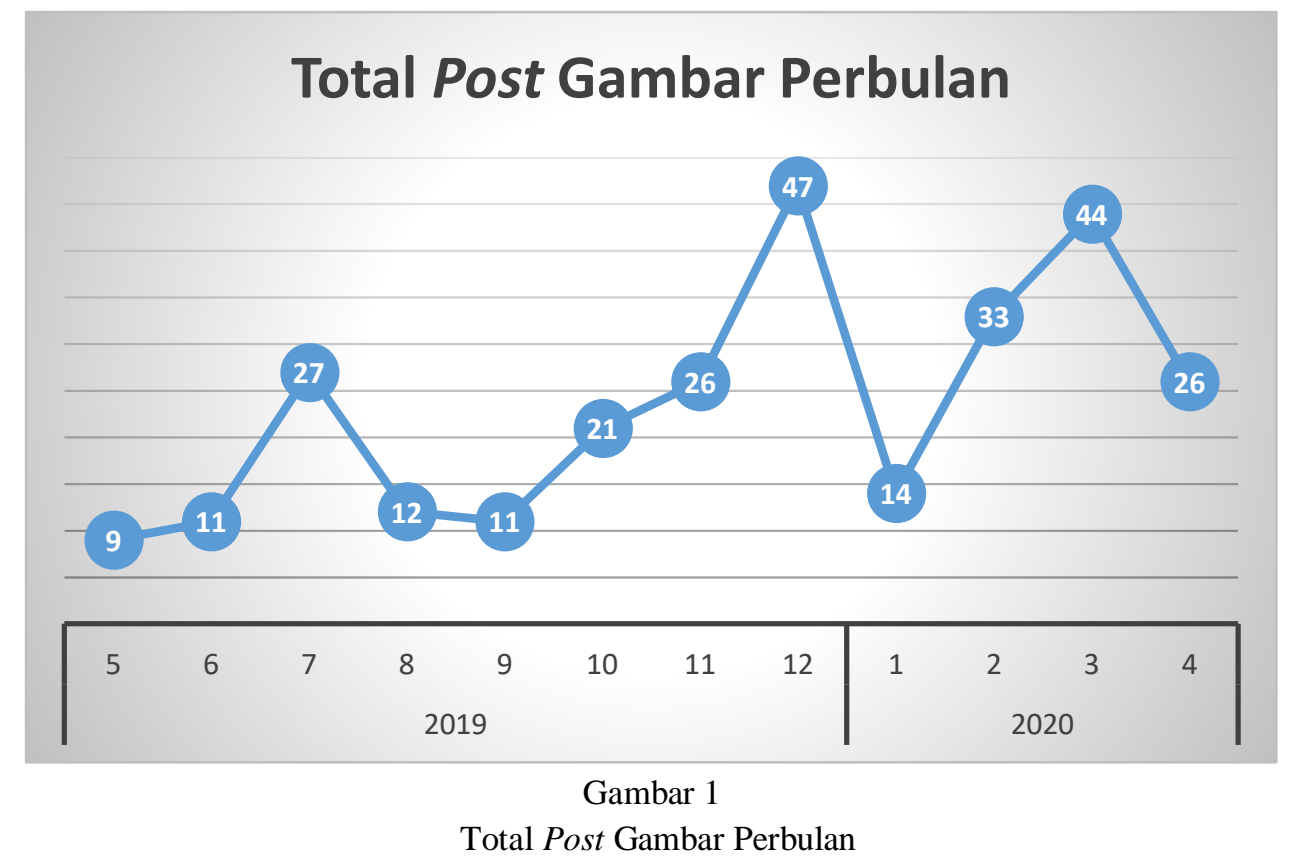

Dari 281 gambar post yang terdapat dalam grup Facebook "Komunitas Peduli HBV (Hepatitis B virus)" sejak bulan Mei 2019 hingga bulan April 2020, peneliti mendapati setidaknya terdapat 173 nama akun Facebook yang berbeda. Artinya terdapat akun Facebook yang melakukan post gambar lebih dari satu. Selain itu terdapat pula akun Facebook yang melakukan post gambar beberapa kali di waktu yang berbeda pula. Misalnya akun dengan nama Astiealfredo yang melakukan post gambar sebanyak 8 buah, serta akun dengan nama Nurbasir Emin yang melakukan post gambar sebanyak 7 buah. Meskipun peneliti tidak memiliki kemampuan untuk menilai dengan cepat dan efektif dalam menentukan manakah akun facebook tersebut yang mencerminkan penggunanya serta manakah akun tersebut yang tidak mencerminkan penggunanya, namun peneliti semakin yakin bahwa grup tersebut adalah grup yang aktif. Terlebih belum menghitung jumlah post yang bukan gambar serta jumlah komentar dalam setiap post-nya, semakin membuat peneliti yakin bahwa grup Facebook "Komunitas Peduli HBV (Hepatitis B virus)" merupakan grup yang aktif dan digunakan sebagai sarana komunikasi antar anggotanya.

Pada pembahasan mengenai kesadaran privasi, peneliti melakukan kategorisasi postingan gambar menjadi tiga kategori. Kategori pertama yaitu gambar yang tidak memiliki relevansi terkait kesadaran privasi, kategori kedua yaitu gambar yang menunjukkan kesadaran privasi, dan kategori ketiga yaitu gambar yang menunjukkan ketidaksadaran privasi. Pada kategori pertama yaitu gambar yang tidak memiliki relevansi terkait kesadaran privasi, peneliti memasukkan gambar-gambar misalnya tanaman obat, obat herbal, quotes tokoh, screenshot artikel, dan lain-lain ke dalam kategori tersebut. Hal ini dikarenakan gambar-gambar tersebut peneliti yakini tidak mengandung unsur-unsur yang memiliki risiko akan privasi seseorang. Gambar 2 merupakan salah satu contoh postingan oleh anggota grup yang masuk pada kategori pertama. 


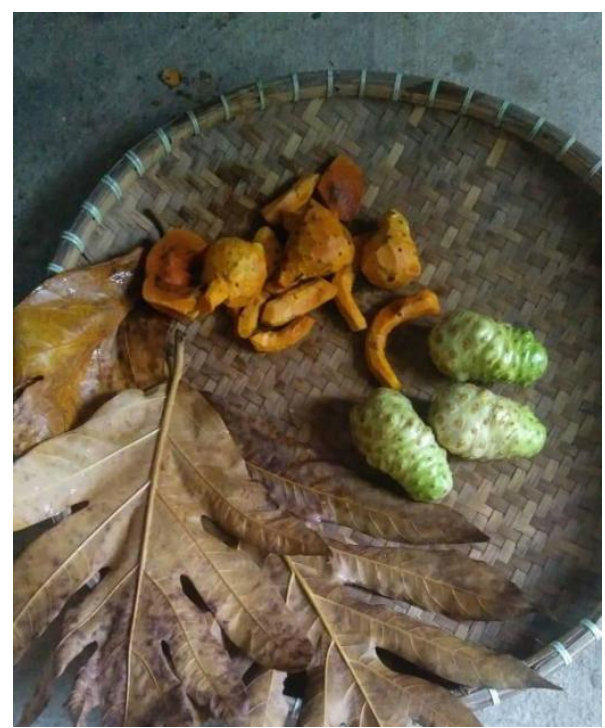

Gambar 2

Obat Herbal (Temulawak, Daun Sukun, dan Mengkudu)

Pada kategori kedua, gambar yang menunjukkan kesadaran privasi, peneliti memasukkan gambar-gambar yang berupa hasil tes laboratorium. Pada gambar kategori kedua, peneliti simpulkan bahwa akun yang melakukan posting gambar berupa hasil tes laboratorium namun dengan sengaja menutupi bagian informasi sensitif termasuk misalnya: nama, alamat, usia, nomor rekam medis, nomor jaminan kesehatan, dan lain-lain merupakan anggota grup yang mempunyai kesadaran privasi. Gambar 3 merupakan salah satu contoh postingan oleh anggota grup yang masuk pada kategori kedua. Catatan, gambar yang terdapat dalam penelitian ini merupakan gambar yang diunduh dari halaman Facebook sehingga resolusi maupun ukuran menjadi tidak maksimal, namun pemilihan gambar yang ditampilkan merupakan gambar yang tetap representatif.

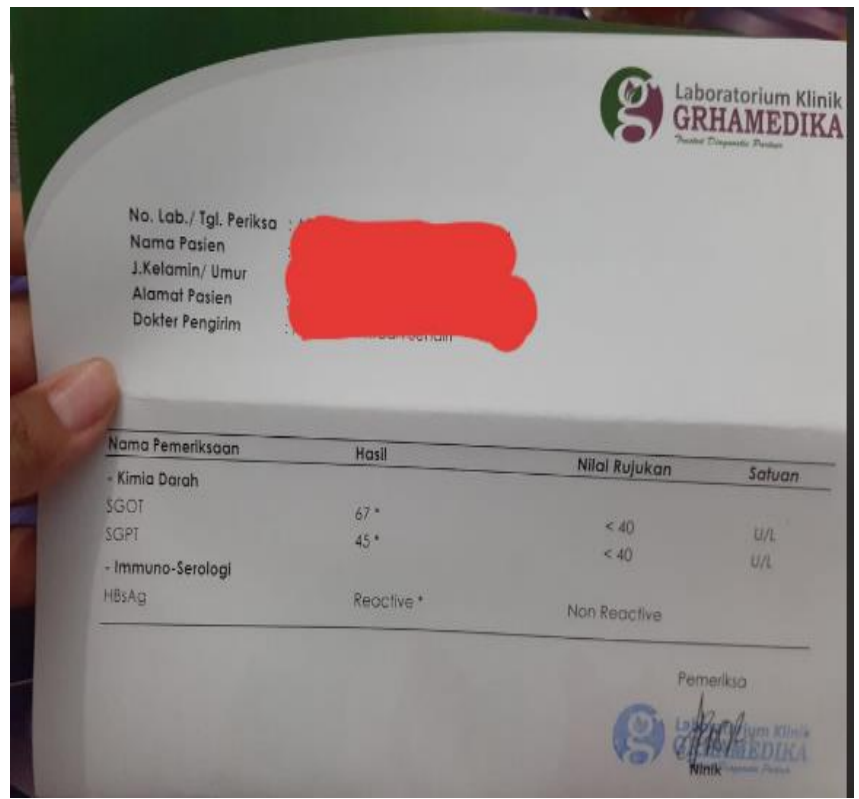

Gambar 3

Hasil uji laboratorium hepatitis B yang sengaja ditutup pada bagian tertentu

Sementara pada kategori ketiga, gambar yang menunjukkan ketidaksadaran privasi, peneliti memasukkan gambar-gambar yang berupa hasil tes laboratorium namun dalam gambar tersebut tidak terdapat unsur menyembunyikan informasi sensitif. Artinya dari post gambar yang dikirim oleh akun tersebut dapat terlihat informasi sensitif seperti misalnya nama, alamat, usia 
(mencerminkan tanggal lahir), nomor rekam medis, nomor jaminan sosial, dan lain-lain. Gambar 4 merupakan salah satu contoh postingan oleh anggota grup yang masuk pada kategori ketiga.

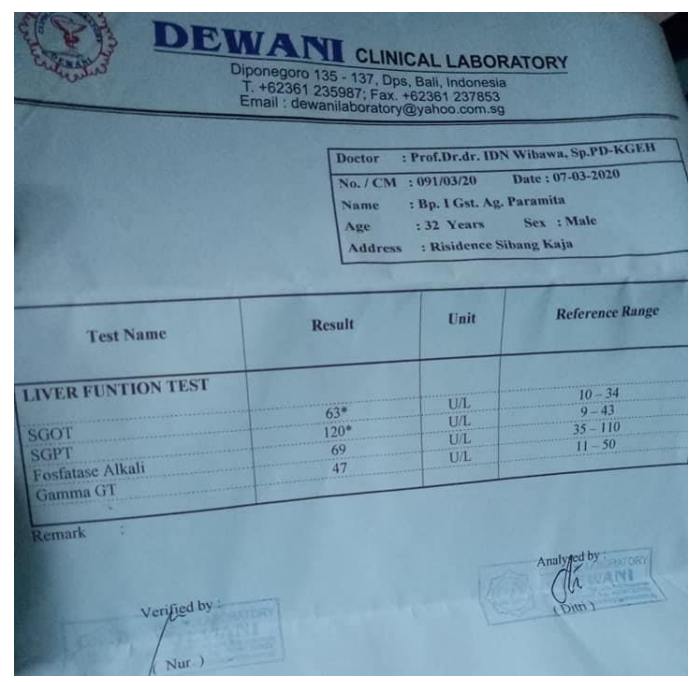

Gambar 4

Hasil uji laboratorium hepatitis B

Dari hasil analisis gambar dalam grup Facebook "Komunitas Peduli HBV (Hepatitis B virus)" sejak bulan Mei 2019 hingga bulan April 2020, didapati hasil sebagai berikut (lihat Gambar 5): Dari 281 gambar, 151 gambar di antaranya termasuk kategori pertama yakni tidak memiliki relevansi terkait kesadaran privasi, 91 gambar di antaranya termasuk kategori kedua yakni menunjukkan kesadaran privasi, serta 39 gambar di antaranya termasuk kategori ketiga yakni menunjukkan ketidaksadaran privasi. Jika dihitung dalam satuan persentase, maka 53.8 persen dari total gambar tidak memiliki relevansi terkait privsi, 32.3 persen dari total gambar menunjukkan kesadaran privasi, serta 13.9 persen menunjukkan ketidaksadaran privasi. Apabila hanya diamati lebih seksama pada data gambar yang memiliki risiko akan privasi, maka terdapat 130 gambar yang memiliki risiko akan privasi. Adapun 70 persen di antaranya menunjukkan kesadaran akan privasi, namun 30 persen sisanya menunjukkan ketidaksadaran privasi. Artinya secara sederhana dapat kita simpulkan bahwa setidaknya terdapat 30 persen pengguna grup Facebook "Komunitas Peduli HBV (Hepatitis B virus)" berisiko terhadap permasalahn privasi. Hal yang lebih ekstrim yaitu jika kita sebut bahwa 3 dari 10 orang berisiko terhadap permasalahan privasi akibat ketidaksadaran mereka akan privasi. Tentu saja simpulan tersebut bersifat tricky, mengingat satu akun dapat mengirimkan post berupa gambar lebih dari satu bahkan dapat mengirimkan gambar di hari yang berbeda.

Mengingat bahwa satu akun dapat mengirimkan gambar lebih dari satu, serta dapat mengirimkan gambar di waktu yang berbeda sehingga peneliti mencoba menggali lebih dalam terkait data yang menunjukkan ketidaksadaran privasi. Dari 39 postingan gambar yang masuk kategori ketiga, yakni menunjukkan ketidaksadaran privasi, peneliti mendapati sejumlah 25 akun yang menjadi pengirim gambar dalam kategori tersebut. Artinya benar bahwa satu akun dapat mengirimkan lebih dari satu gambar. Lebih lanjut, dari 25 akun tersebut peneliti menemukan bahwa terdapat akun yang melakukan post gambar dengan tanggal berbeda yakni pada akun I Gusti Agung Paramita dan akun Edi Kurniawan. Pada Akun I Gusti Agung Paramita, peneliti menemukan 3 gambar yang diposting pada tanggal 15 April 2020 yang menunjukkan bahwa terdapat informasi sensitif berupa nama lengkap (sesuai dengan nama akun Facebook: I Gusti Agung Paramita), usia yakni 32 Tahun, Alamat yakni Sibang Kaja Bali, serta nomor rekam medis. Pada Akun Edi Kurniawan, peneliti menemukan bahwa 2 gambar yang diposting pada tanggal yang berbeda yakni pada tanggal 6 dan 7 April 2020 yang menunjukkan terdapat informasi sensitif berupa nama lengkap (sesuai dengan nama akun Facebook: Edi Kurniawan), usia yakni 25 tahun. Artinya adalah 
orang-orang tersebut menjadi semakin berisiko akan permasalahan privasi mengingat mereka menggunakan nama akun Facebook yang sesuai dengan nama pribadi mereka serta melakukan ekspos informasi pribadi di dunia maya di mana semua orang berpotensi untuk melihatnya.

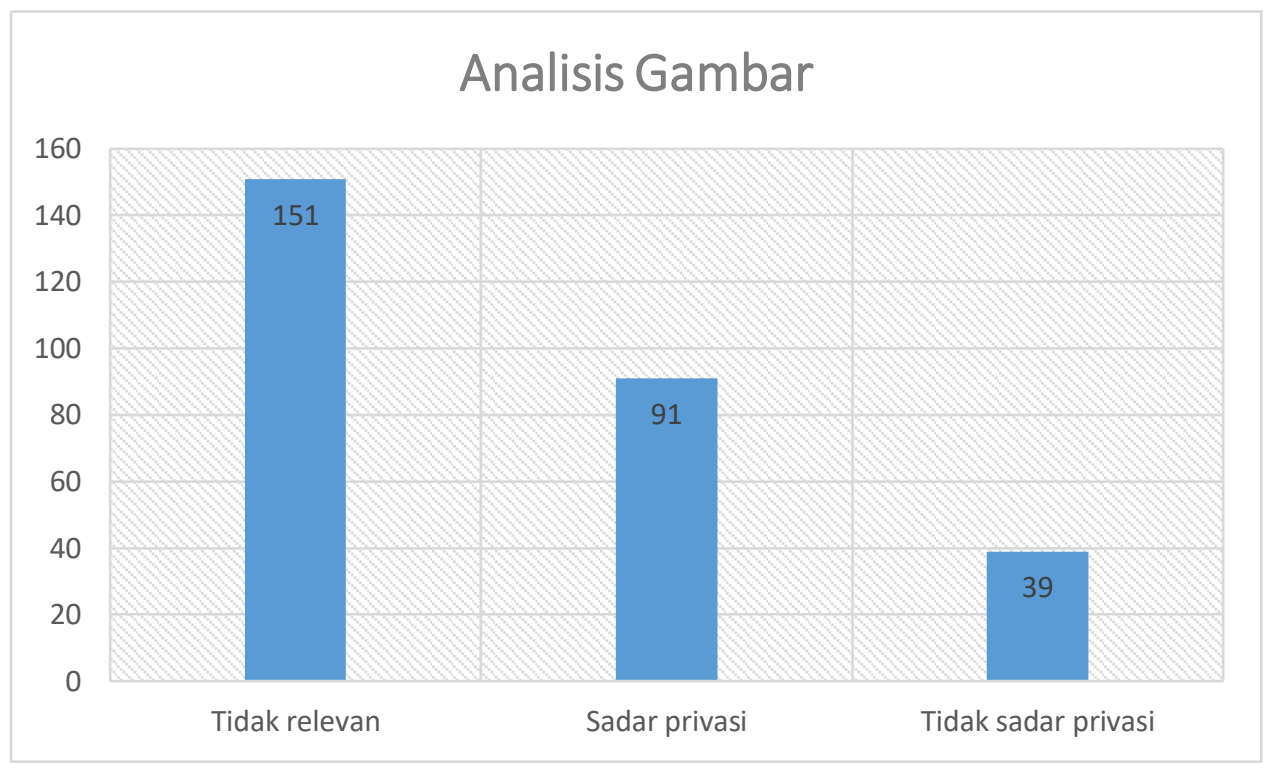

Gambar 5

Grafik kategorisasi postingan gambar pada grup Facebook Peduli HBV

Adapun terdapat poin yang penting untuk diingat terkait dampak ketidaksadaran privasi termasuk di antaranya adalah diskriminasi. Pengeksposan informasi sensitif di media sosial dapat berdampak tidak hanya diskriminasi di media sosial, tetapi juga dapat berdampak pada diskriminasi di lingkungan sosial sehari-hari. Hal ini terutama apabila terdapat teman, rekan kerja, atau orang yang sesekali berinteraksi menemukan informasi sensitif tersebut di media sosial yang sifatnya bisa diakses siapa saja. Maka dari itu, menjadi penting sebuah kesadaran privasi bermedia khususnya bagi mereka pengidap virus hepatitis yang berisiko mendapatkan diskriminasi karena mengekspos informasi sensitif di media sosial. Bagi peneliti, konsep kesadaran privasi dapat disebarkan kepada anggota lainnya agar mereka menjadi sadar privasi dalam bermedia sehingga mengurangi dampak-dampak negatif yang berisiko terjadi. Maka saran dari peneliti terhadap anggota komunitas tersebut adalah mereka saling aktif untuk mengingatkan anggota lainnya agar menjadi sadar privasi, terutama bagi mereka yang tergolong $70 \%$ orang yang masuk kategori sadar privasi. Sehingga ke depan persentase kesadaran privasi dalam bermedia menjadi semakin tinggi, bahkan jika memungkinkan sudah tidak ditemukan lagi seseorang yang tidak memiliki kesadaran privasi.

Merujuk pada kerangka kerja literasi digital yang disebutkan Dana Rotman (2009) mulai dari memahami hingga memutuskan, maka interpretasi peneliti terhadap temuan di atas adalah masyarakat Indonesia ternyata belum sepenuhnya memiliki kesadaran privasi. Angka 30\% tingkat ketidaksadaran privasi sebagaimana temuan di atas memanglah merupakan kasuistik. Akan tetapi, apabila menengok kembali pada konteks di atas bahwa terdapat urgensi menjaga privasi maka angka 30\% menjadi angka yang patut disayangkan. Asumsi peneliti selanjutnya adalah bahwa jika dalam kasus di mana terdapat urgensi menjaga privasi saja menunjukkan tingkat yang demikian maka dalam kasus yang lebih luas akan menunjukkan angka yang lebih tinggi. Asumsi peneliti tersebut dilandasi bahwa kasus yang lebih luas meniadakan conflict of interest di mana pengguna sosial media tidak mempertaruhkan dampak secara langsung akibat pengungkapan privasi di sosial media. Dana Rotman (2009) memang menyebutkan kerangka kerja literasi digital mulai dari memahami, mengenali, menyadari, mengevaluasi, hingga memutuskan, namun dalam konteks ini peneliti cenderung pesimis terhadap pengguna sosial media di Indonesia dalam penerapan teori 
tersebut. Dari temuan di atas, peneliti melihat bahwa pengguna sosial media sangat memerlukan semacam pendidikan privasi sebelum aktif di dalamnya.

Hasil penelitian di atas cukup representatif dalam menjawab pertanyaan penelitian, di mana ukuran tingkat kesadaran privasi di sosial media menjadi jelas dalam kasus tertentu. Hal yang juga penting diperhatikan selanjutnya terkait penelitian ini adalah penelitian ini mengambil sampel kurun waktu satu tahun. Artinya masih terbuka lebar peluang untuk pengembangan penelitian misalnya berupa melihat tren dari tahun sebelumnya dan tahun setelahnya. Apabila telah dilakukan penelitian lanjutan dengan melihat tren dari tahun ke tahun, tentu akan terlihat adakah fluktutasi atau bahkan pola-pola tertentu yang muncul dari tingkat kesadaran privasi di sosial media. Sosial media bagi peneliti merupakan sebuah cermin yang tepat untuk mengukur tingkat kesadaran privasi sehingga penelitian lanjutan yang juga berbasis sosial media tentu masih relevan. Sosial media memberikan fitur anonimitas yang memungkinkan pengguna untuk menentukan sejauh mana ia akan mengungkap privasinya dan dari pengungkapan itulah menjadi salah satu tolok ukur dalam menilai tingkat kesadaran privasi. Selain penelitian yang menggunakan ukuran kuantitatif, perlu disadari pula pentingnya penelitian dengan menggunakan pendekatan kualitatif. Hal ini misalnya untuk menjawab fenomena-fenomena mendalam sebagaimana yang disebutkan oleh Rotman (2009) bahwa terdapat kemungkinan bahwa pada tahap memutuskan (deciding), seorang sebenarnya sudah memahami hingga mengevaluasi namun tetap memilih untuk memutuskan dan mengungkapkan bagian tertentu dari privasinya. Hal tersebut menjadi menarik untuk mengamati pengungkapan privasi atas dasar kesengajaan yang tidak mampu dibahas dalam penelitian ini.

\section{SIMPULAN}

Kategorisasi postingan gambar/foto pada grup Komunitas Peduli HBV menjadi 3 kategori yaitu gambar yang tidak memiliki relevansi terkait kesadaran privasi, gambar yang menunjukkan kesadaran privasi, dan gambar yang menunjukkan ketidaksadaran privasi.

Selama rentang waktu antara Mei 2019 hingga April 2020 terdapat sebanyak 281 postingan gambar/foto. Hasil dari penelitian ini mengungkapkan bahwa dari 281 postingan gambar terdapat 151 gambar yang tidak memiliki relevansi dengan kesadaran privasi, 91 gambar yang menunjukkan kesadaran privasi, serta 39 gambar yang menunjukkan ketidaksadaran privasi. Jika berfokus mengamati gambar yang memiliki relevansi terhadap kesadaran privasi, maka didapati 130 gambar atau dengan persentase $70 \%$ menunjukkan kesadaran privasi dan 30\% menunjukkan ketidaksadaran privasi. Peneliti menyimpulkan bahwa masih terdapat $30 \%$ pengguna Facebook, terutama anggota grup tersebut yang notabene cenderung menyembunyikan identitasnya sebab alasan diskriminasi, menunjukkan ketidaksadaran privasi. Hal ini dapat membuka peluang untuk dilakukan penelitian selanjutnya terkait kesadaran privasi di dunia digital yang tidak terbatas pada kasus penyakit saja.

\section{DAFTAR PUSTAKA}

Asosiasi Penyedia Jasa Internet Indonesia. (2019). Laporan Survei : Penetrasi \& Profil Perilaku Pengguna Interneet Indonesia. Buletin APJII, Edisi 40 (Mei), 1-6. Retrieved from https://apjii.or.id/survei

Barth, S., de Jong, M. D. T., Junger, M., Hartel, P. H., \& Roppelt, J. C. (2019). Putting the privacy paradox to the test: Online privacy and security behaviors among users with technical knowledge, privacy awareness, and financial resources. Telematics and Informatics. https://doi.org/10.1016/j.tele.2019.03.003

Batmetan, J. R., Kariso, B., Moningkey, M., \& Tumembow, A. (2018). Tingkat Kesadaran Privasi Atas Masalah Keamanan Informasi. 4. https://doi.org/10.31219/OSF.IO/CAHZR

Citizen.org. (2012). HIV/AIDS and Hepatitis B in Indonesia - Public Citizen. Retrieved from 
https://www.citizen.org/article/hiv-aids-and-hepatitis-b-in-indonesia/

DePuccio, M., DiTosto, G., Walker, D. M., \& McAlearney, A. S. (2020). Patients' Perceptions about Medical Record Privacy and Security: Implications for Withholding of Information During the COVID-19 Pandemic. Journal of General Internal Medicine, In press. https://doi.org/10.1007/s11606-020-05998-6

Detik. (2018). Miris, 50 Persen Pengidap Hepatitis Alami Diskriminasi di Kantor. Retrieved from https://health.detik.com/berita-detikhealth/d-4138947/miris-50-persen-pengidap-hepatitis-al ami-diskriminasi-di-kantor

Dijk, J. van. (2012). The Network Society. SAGE Publications.

Givens, C. L. (2014). Information privacy fundamentals for librarians and information professionals. Maryland: Rowman \& Littlefield.

Han, B., Yuan, Q., Shi, Y., Wei, L., Hou, J., Shang, J., ... Cui, F. (2018). The experience of discrimination of individuals living with chronic hepatitis $B$ in four provinces of China. https://doi.org/10.1371/journal.pone.0195455

Kriyantono, R. (2014). Teknik praktis riset komunikasi. Prenada Media.

Le, T., Vu, T., Mai, H., Nguyen, L., Truong, N., Hoang, C., ... Ho, R. (2019). Social Determinants of Stigma and Discrimination in Vietnamese Patients with Chronic Hepatitis B. International Journal of Environmental Research and Public Health, 16(3), 398. https://doi.org/10.3390/ijerph16030398

Nadila, B., \& Rahman, Y. (2019). Perancangan Media Visual Kampanye Mengenaihepatitis B Dan Pencegahannya (Imunisasi). EProceedings of Art \& Design, 193.

Park, Y. J. (2013). Digital Literacy and Privacy Behavior Online. Communication Research. https://doi.org/10.1177/0093650211418338

Potter, J. (2019). Media Literacy. In Sage. https://doi.org/10.1017/CBO9781107415324.004

Prananda, R. R. (2020). Batasan Hukum Keterbukaan Data Medis Pasien Pengidap Covid-19: Perlindungan Privasi VS Transparansi Informasi Publik. Law, Development \& Justice Review, 3(1), 142-168. https://doi.org/10.14710/LDJR.V3I1.8000

Republika. (2017). Penderita Hepatitis Sering Alami Diskriminasi Kerja | Republika Online. Retrieved from https://www.republika.co.id/berita/gaya-hidup/info-sehat/17/10/22/oy73gp328-penderita-he patitis-sering-alami-diskriminasi-kerja

Rotman, D. (2009). Are You Looking At Me? Social Media and Privacy Literacy . Proceedings of the $2009 \quad$ IConference, 15-17. Retrieved from http://www.danarotman.com/wp-content/uploads/2010/07/Are-You-Looking-at-Me-SocialMedia-And-Privacy-Literacy.pdf

Saidah, M., \& Irwansyah. (2019). Kebebasan berekspresi dan paradoks privasi dalam hubungan pertemanan. Jurnal Studi Komunikasi (Indonesian Journal of Communications Studies), 3(2), 215. https://doi.org/10.25139/jsk.v3i2.1683

Sugiyono, P. (2015). Metode penelitian kombinasi (mixed methods). Bandung: Alfabeta.

Wissinger, C. L. (2017). Privacy literacy: From theory to practice. Communications in Information Literacy, 11(2), 378-389. https://doi.org/10.15760/comminfolit.2017.11.2.9

Yano, Y., Utsumi, T., Lusida, M. I., \& Hayashi, Y. (2015). Hepatitis B virus infection in Indonesia. World Journal of Gastroenterology, 21(38), 10714-10720. https://doi.org/10.3748/wjg.v21.i38.10714 
Lentera Pustaka: Jurnal Kajian Ilmu Perpustakaan, Informasi dan Kearsipan, 6 (2) 2020, 119-130 